УДК 347.764(9)

DOI https://doi.org/10.32837/pyuv.v0i3(32).596

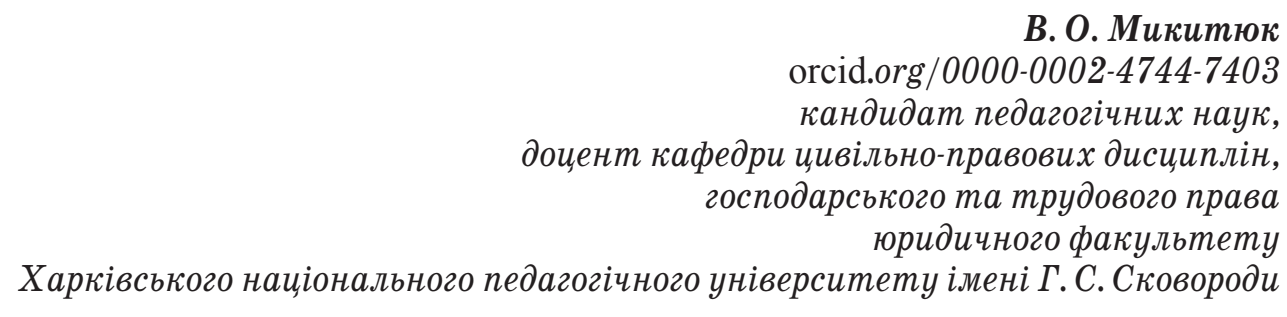

\title{
СТРАХОВІ ВІДНОСИНИ ЯК НЕОБХІДНИЙ ЕЛЕМЕНТ ФУНКЦІОНУВАННЯ СУСПІЛЬСТВА
}

Постановка проблеми. Страхування є засобом охорони майнових і особистих інтересів кожної людини. Чи було так завжди? Звертаючись до витоків страхування, можна відзначити наявність багатьох різних точок зору з приводу цього питання, що свідчить про його актуальність. Звернення до процесу еволюції страхових відносин потребує паралельного дослідження стану розвитку суспільства, відносин між основними верствами (станами) суспільства, рівня розвитку торговельних і договірних відносин, що свідчить про тісний зв'язок страхування з іншими суспільними (економічними, політичними, соціальними) процесами.

Стан дослідження. Страхування, історія його виникнення завжди цікавила науковців як минулого, так і сьогодення. Вже на початку ХХ століття з'явилися значна кількість статей і праць, присвячених цій тематиці, серед яких можна виокремити працю професора Київського університету і Комерційного інституту К. Воблого «Основи економії страхування» (1915р.) [1], в якій порушувалися питання історії страхування, видів страхування, страхового полісу та ін., підкріплених статистичними даними діяльності страхових товариств. При цьому страхові відносини досліджувались як складові елементи економічної системи і перебували під впливом «базових» економічних відносин.

Перші спроби виокремити страхові відносини як окрему категорію і довести наявність зародків страхування у ранній період функціонування суспільства можна простежити у працях В. Райхера «Суспільно-історичні типи страхування» [2], С. Рибнікова «Нариси з історії страхування» [3].

Про актуальність питань, пов'язаних зі страхуванням, свідчить значна кількість статей у друкованих виданнях початку XX століття - Віснику взаємного страхування (1911 р.) та Віснику цивільного права, в яких обговорювались питання необхідності такого виду страхування, як страхування від вогню.

Значний внесок у розв'язання актуальних проблем для сучасного етапу розвитку страхових відносин зробили такі вчені-правознавці, як А. Єрмошенок, А. Зальотов, О. Слюсаренко, В. Ба- зилевич, В. Шапран та ін., які зверталися до вивчення певних видів страхування (добровільного й обов'язкового), страхового випадку як підстави отримання страхового відшкодування та ін.

Однак страхові відносини загалом як системна категорія досліджені не досить. Відсутнє комплексне бачення місця і ролі страхових відносин як необхідного елемента функціонування суспільства.

Метою статті є дослідження еволюції страхових відносин, результатом якої стало їх закріплення як невід'ємного елемента функціонування суспільства.

Виклад основного матеріалу. Суспільні відносини - це різноманітні відносини між соціальними спільнотами і всередині них. Система суспільних відносин характеризується наявністю багатьох внутрішніх і зовнішніх факторів взаємовпливу i взаємодії, які є причиною різноманітних змін. За своєю предметною спрямованістю суспільні відносини, відповідно до сфер життєдіяльності суспільства, поділяються на економічні, соціальні, політичні, моральні та інші. Одним із важливих і необхідних елементів суспільства є страхові відносини, які починаючи з моменту їх виникнення мали істотне значення для існування, діяльності людей та захисту кожної особистості.

Так, на початковому етапі існування суспільства окрема особа була незахищеною перед небезпекою природних явищ і надзвичайними подіями, тому в основному суспільні відносини мали соціально-груповий характер, що передбачало об’єднання у групи, колективи. Це давало змогу об'єднати зусилля для захисту людини від наслідків впливу руйнівних природних явищ і організувати взаємодопомогу у разі необхідності. Очевидно, що така практика як цілком виправдана передавалася $з$ покоління в покоління. Вона вдосконалювалася й поширювалася на інші землі.

Зародки страхових відносин можна віднайти, на думку В. Абрамова, ще у Фінікії на берегах Перської затоки, де між купцями укладалася угода про взаємний розподіл збитків у разі аварії корабля та інших небезпек [4, с. 7].

На території Стародавньої Індії, Стародавнього Єгипту створювалися організації, які надавали 
матеріальну допомогу їх членам у разі необхідності, а у випадку смерті особи - осиротілим сім'ям. Важко визначити, чи існував у них постійний страховий фонд, але допомога виплачувалася в порядку розкладки на всіх членів організації. Однак, на думку В. Райхера, можна вважати встановленим, що це були організації взаємодопомоги, які діяли в певному колективі [2, с. 43].

3 розвитком суспільства поступово організація страхування почала змінюватися та акумулюватися на основі постійного фонду. Тобто страхування переходить до більш досконалої форми: від розкладки збитку до регулярних страхових платежів. Однак ще тривалий час ці дві форми страхування існували разом, розкладка збитку переважно у сфері торгівлі, а регулярні платежі - ремесла $[2$, c. 47$]$.

Більш чітко діяльність організацій статутного типу з обов' язковими страховими внесками існувала у Стародавньому Римі. Тут діяли такі категорії корпорацій: професійні, релігійні, військові, які розташовувалися не тільки в місті Римі, але і по всій Італії, в римських провінціях [2, с. 43].

До римських професійних спілок (collegia) входили ремісники і робітники різних професій: ковалі і каменярі, гончарі і склярі, мідники і ювеліри тощо. Близько до них за характером були колегії матросів, рибалок, землемірів, банщиків. Далі - колегії купців, що торгували хлібом, винами, лісом [2, с. 45]. Їх можна вважати яскраво вираженими організаціями взаємного страхування на випадок смерті. Для того щоб стати членом професійної спілки, слід було зробити вступний внесок у розмірі 100 сестерцій і амфору «доброго вина», потім щомісячно сплачувати по 5 асів. У разі смерті члена колегії спочатку сплачувались 300 сестерцій як витрати на поховання, з яких 50 сестерцій утримувалися для роздачі учасникам похоронної процесії. Основна виплата була спрямована на організацію гідного поховання. Ця виплата могла бути виплачена тільки спадкоємцю за заповітом, а не за законом. Це пояснювалося тим, що лише особа, вибрана самим померлим, могла виконати основне зобов'язання про поховання. Навіть за відсутності заповіту гроші не видавалися законному спадкоємцю. Поховання в такому разі відбувалося за рахунок визначеної суми самою колегією. Потім така ж сума могла бути виплачена і для підтримки осиротілої сім’ї [1, с. 12].

Додатковою охороною основного призначення похоронних сум слугувала i їх недоторканність для кредиторських стягнень. Також усі угоди, які укладалися рабами, належали їх господарю, останній не мав права на отримання похоронних виплат у разі його смерті. Особа позбавлялася права на отримання страхової суми у разі самогубства або несплати місячного внеску у визначений строк $[1$, с. 13]. Члени колегії мали право на отримання їх частки в колегіальному майні під час її ліквідації. Для регулювання відносин взаємодопомоги існував чіткий юридичний механізм, закріплений нормами статутів або угодами колегій.

Крім релігійних, професійних колегій, у Стародавньому Римі особливу групу становили військові колегії, які можна вважати початком особистого страхування. Бо військова справа ще в період республіки виокремилася в особливу професію або "ремесло», в якій грошове забезпечення відігравало більшу роль, ніж у звичайних ремісників, а витрати, пов'язані з їі проходженням, покладалися на самих військовослужбовців, що і створило сприятливі умови для розвитку страхування [3, с. 53].

Зародження страхових відносин відбувалося i на території України, що було зумовлене активним розвитком шляхової торгівлі. Так, за часів Київської Русі існувала караванна торгівля купців-воїнів, найчастіше з Візантією, що здійснювалася на підставі договорів [5]. За історичними відомостями це був особливий торговельно-військовий похід великого каравану човнів з товарами (раби, хутро), що належали князям, їх дружині і окремим купцям-воїнам. Усі збитки від такого походу розкладалися на весь караван.

Однак більш яскравим прикладом страхової солідарності були українські чумаки. Чумацтво, про яке існують свідчення починаючи з XIII ст., досягло свого повного розквіту у XVI-XVII ст. і продовжувало відігравати важливу роль в українській торгівлі до появи залізниці. Чумаки їдили за рибою і сіллю до берегів Чорного і Азовського морів, продавали ці товари на ярмарках, закупали там інші і розвозили їх в інші міста. Вони здійснювали свої подорожі караванами («валками», «ватагами») на підводах, запряженими волами. y XV столітті чумацтво було тісно пов'язане 3 розвитком козацтва загалом і Запорозької Січі зокрема. «Під заступництвом козацтва і матері Запорозької Січі щорічно сотні і тисячі чумацьких возів, нерідко належних самим козакам, ходили далеко в Польщу, Галіцію, Молдавію, Крим, на Дон» [5, с. 55].

Чумаки були тоді єдиними національними торговцями і візниками. Упродовж більш пізнього періоду чумацтво було вже складеним і завершеним економічним фактором, мало у своїй основі міцні осереднені артільні форми. Тобто були добровільними об'єднаннями людей для сумісної колективної діяльності, які функціонували на підставі звичаїв і законів. Тому участь кожного у торговельному каравані відображалася у загальних доходах і загальній відповідальності на основі кругової поруки. Серед звичаїв чумацької артілі, наприклад, був такий, що чумаки повинні відправлятися в путь з дому завжди караваном у складі до 300 підвід, запряженими волами, і що 
«у разі якщо впаде віл, то на артільні гроші покупається інший» [6, с. 68].

3 огляду на те, що чумацький промисел існував у більш пізній період і мав значний розмах, тому викладене страхове начало було не випадковим явищем, а нормальним інститутом господарювання, що забезпечувало кожному з учасників торговельного колективу за рахунок усіх його членів захист від стихійних та інших небезпек. Саме таке забезпечення, на думку В. Райхера, і було ніщо інше, як страхування.

Слідуючи меті дослідження, необхідно підкреслити, що характерною особливістю страхових відносин стародавнього періоду була ї соціально-групова спрямованість, залежність кожної людини від суспільства загалом. Однак страхові відносини не залишалися незмінними, вони постійно збагачувалися залежно від форм господарювання, рівня їх розвитку, залежно від статусу різних суб'єктів у соціальній структурі суспільства, функціонування публічної влади та інших важливих факторів.

Слід зазначити, що всі форми страхування стародавнього періоду, починаючи з угоди про розкладку збитків і до статутів римських колегій, зникли на декілька століть після розпаду Римської Імперії, але подібні до них почали з'являтися в період Середньовіччя у нормах звичаєвого права. Так, на думку В. Райхера, у Середньовіччі розвиток страхування відбувався заново, поза прямим історичним наступництвом зі страхуванням античного суспільства [2, с. 58].

Розвиток суспільства, торгівлі, ремесла в період Середньовіччя спричинили подальший розвиток і вдосконалення соціально-професійних відносин (діяльність цехів, гільдій) і суспільно-політичних явищ - збільшення кількості міст і міського населення, виникнення міського права, розширення самостійності в управлінні окремих міст. Усі ці явища і події вплинули на необхідність підвищеного захисту населення від непередбачуваних небезпек і спричинили удосконалення страхових відносин, а саме виникнення нових видів страхування як майнового та особистого, виділення гільдій, цехів, що вплинуло на необхідність створення спеціальних страхових фондів на професійній основі.

Так, починаючи з IX ст. відбувається інтенсивний розвиток міст у Північній і Середній Італії, які досить швидко багатіли завдяки посередницькій торгівлі між Сходом і Заходом, ремісничому виробництву, кредитно-грошовим операціям. Венеція, Генуя, Піза мали сильний флот та вели жваву торгівлю з країнами Середземномор'я. Деякі міста славилися окремими ремеслами. Мілан, наприклад, став центром зброярства, у Павії були найкращі кушніри, Лукка була відома виготовленням якісного сукна, Венеція - виробами зі скла.
Міські статути закріплювали привілеї, здобуті містами. Варто наголосити на системі привілеїв, серед яких виділялися привілеї у власному судочинстві і привілеї економічного спрямування. Серед економічних найпоширенішими були податкові торговельні привілеї. Торговельні привілеї стали основою для економічного зростання багатьох європейських середньовічних міст. Так, у 1082 р. Венеція отримала Хартію свобод від візантійського імператора, яка гарантувала їй свободу транзитної торгівлі і звільнення від будь-яких податків та зборів на всій території Візантійської імперії. Цей привілей дав змогу Венеції монополізувати європейську торгівлю зі Сходом і закласти основи економічної могутності.

Завоювання містами політичної самостійності сприяло швидкому зростанню їх економічної могутності. Основу економіки становив розвиток ремесла, шо спричинило виникнення нових спеціальностей і цехів. Наприклад, у містах Північно-Східної Франції існувало 25 спеціальностей. В Ам'єні число ремісничих спеціальностей, організованих у цехи, дорівнювало 80, в Аббевілі 64, у Сен-Кантені - 53. У другій половині XIII в. за рішенням прево (посадової особи короля) Парижа Етьєна Буало були створені статути 100 цехів («Книга ремесел Парижа»), зокрема, 22 цехи лише у галузі виробництва металевих виробів. До початку XIV ст. число зареєстрованих цехів у Парижі досягло 350 [7, с. 24-25].

Особливим джерелом середньовічного права стають статути цехів - середньовічних корпорацій ремісників, тобто ремісничих професійних спілок. Таке ремісниче об'єднання зазвичай не передбачало спільної діяльності або розподілу праці, оскільки в ньому об'єднувалися представники однієї професії. Головним завданням цеху був захист майнових і немайнових прав його членів. Кожен цех контролював сферу своєї діяльності і ринок продукції. Цехи всіляко переслідували ремісників, які намагалися працювати за межами цеху, боролися проти втручання інших майстрів у сферу їхньої діяльності. У більшості середньовічних міст органи самоврядування намагалися докладно регламентувати і контролювати діяльність цехів. Структура цехових статутів охоплювала преамбулу, норми, які регулювали вступ до цеху, права й обов'язки цехових майстрів та підмайстрів, трудові відносини між ними, порядок участі цехів у міському самоврядуванні тощо. Статути цехів також містили вимоги щодо поведінки їніх членів, зокрема, участі в обороні міста, у релігійних обрядах, в управлінні цехом, передбачали вимоги щодо якості продукції і взаємодопомоги [7, с. 27].

У Середньовіччі страхові відносини поступово поширювалися й на інші ризики, здійснювались через гільдії (братства). Згодом гільдії почали 
спеціалізуватися за окремими професіями, з'явилися й захисні гільдії, що мали завданням охорону особи й майна від різних зазіхань. Принцип взаємодопомоги закріплювався у статуті гільдії. Поступово формувався перелік страхових подій і уточнювався розмір внесків і виплат.

Ускладнення і розвиток торговельних, договірних і різних форм страхових відносин призвів до виникнення i діяльності ділових асоціацій i спільних товариств. На Півдні Європи Венеція, Флоренція, Генуя, Севілья, Мадрид розвивали торговельні відносини, утворюючи компанії і товариства. Перша компанія - об’єднання на тривалий термін капіталу і праці виникла у Венеції, та найбільшими у Середньовіччі були компанії Флоренції. Від 1072-1073 рр. у Венеції почали укладати угоди про товариство (“colleganza”). Ці товариства були двох видів. У першому компаньйон, який залишався на місці, авансував певну суму грошей мандрівному компаньйону. Після повернення мандрівний компаньйон виплачував суму, отриману при від'їзді, залишав собі четверту частину прибутку, а решту (три чверті) віддавав власнику товариства. В іншому товаристві авансували три чверті суми, а мандрівний компаньйон вкладав свою працю і четверту частку капіталу. У такому разі доходи ділили навпіл. "Colleganza" нагадувала "comenda" інших італійських міст, еквівалент яких знаходимо у Марселі, Барселоні, Севільї [7, с. 30]. Отже, у Середньовіччі закладалися основи морського страхування через спеціально створені страхові товариства.

Збільшення попиту на страховий захист зумовило перехід до продажу страхових полісів 3 подальшим відшкодуванням збитків. Перший морський поліс був виданий у 1347 році. Пізніше з'явилися Кодекси морського страхування: у Барселоні (1435 р.), Венеції (1468 р.). Тож страховий договір став засобом забезпечення будь-якого інтересу, що піддавався ризику. Саме виникнення договору визначало формування страхування i його подальший розвиток.

Зовсім інші страхові відносини формувалися починаючи з XVII-XVIII ст. Активно почала розвиватися страхова справа і виникнення відмінних від морського видів страхування. У багатьох європейських країнах виникли акціонерні страхові компанії (1602 р. створене Голландське Ост-Індське товариство). Страхові компанії Англії, Німеччини, Франції займались морським страхуванням, страхуванням на випадок пожежі, у сільській місцевості - страхуванням посівів від знищення або пошкодження. Прийнятий ще у 1774 році закон про страхування життя лишається в складі чинного законодавства Англії й досі [8].

У 1779 році члени асоціації «Лондонський Ллойд» прийняли «підписаний формуляр Ллойда» (формуляр договору морського страхування), низка положень якого донині застосовуються у міжнародній практиці.

Поява картелів і концернів у страхуванні пов'язана з XIX ст. Один із великих концернів був створений у Берліні в 1874 році. Він діяв як міжнародний і складався 316 страхових товариств, а через 50 років концерн об'єднував уже 230 товариств.

Більш ефективна взаємодія економічних, політичних, страхових відносин відбувається починаючи з XX ст., де страхування стало невід'ємним атрибутом ринкової економіки, що було спричинено розширенням світової торгівлі, збільшенням інвестицій за межами своїх держав. Основні світові тенденції у страхуванні включають поступовий відхід від націоналізації страхування, розробку всесвітніх страхових програм для покриття операцій багатонаціональних корпорацій, збільшення використання перестрахування, розширення використання корпораціями програм самострахування, збільшення використання злиття як між страховиками, так і з брокерськими фірмами [8].

Висновки. Таким чином, страхові відносини $€$ необхідним елементом функціонування суспільства, але еволюція конкретного змісту страхових відносин історично відбувалась разом зі змінами самого суспільства. Поступово виникали і стверджувалися у повсякденному житті людей нові елементи цих відносин, які набували характеру окремих інститутів, що поступово відтворювали і себе, і свої взаємини в рамках цілісної системи. Так, еволюція страхових відносин розпочалася з форми організації взаємодопомоги, поступово перетворившись на захист окремих професійних груп - представників цеху, пізніше - у створення товариств морського страхування. 3 часом страхування набуло міжнародного значення - картелі і концерни (XIX ст.), стало невід'ємною частиною ринкової економіки (з ХX ст.), але протягом усієї історії сприяло захисту груп, окремих індивідів від небезпек і негативних подій, які могли трапитися протягом їхнього життєвого шляху.

\section{Jimepamypa}

1. Воблый К.Г. Основы экономии страхования. Киев : Тип. И.Н. Соколова. 1915. VII. 616 с.

2. Райхер В.К. Общественно-исторические типы страхования. Райхер. Москва : Л. изд. и 1-я тип. изд-ва Акад. наук СССР. 1947. 283 с.

3. Рыбников С. Очерки из истории страхования в России. Вестник государственного страхования. 1927. № 19-20. С. 112-116.

4. Абрамов В.Ю. Страхование: теория и практика. Москва : Волтерс Клувер, 2007. 512 с. URL: https://books.google.com.ua/books?id=0E2cEizSbPsC\&p$\mathrm{g}=\mathrm{PR} 1 \& \mathrm{lpg}=\mathrm{PR} 1 \& \mathrm{dq}=$ Абрамов+ страхование\&source.

5. Щербина Ф. Очерки южно-русских артелей и общинно-артельных форм. Одесса, 1880. 389 с.

6. Микитюк В.О. Становлення та організація страхування в епохи Античності та Середньовіччя. Вісник 
Харківського національного університету ВС. 2009. № 4. C. $66-74$.

7. Кахнич В.С. Міста-держави та міське право в середньовічній Європі: історико-правове дослідження монографія. Львівський національний університет iм. І. Франка, Юридичний факультет. Львів : Галицький друкар, 2014. 139 с

8. Historical Development of Insurance. URL: https://www.Britannica.com/topic/insurance/Historical-development-of-insurance.

\section{Анотація}

Микитюк В. О. Страхові відносини як необхідний елемент функціонування суспільства. Стаття.

У статті автор розглядає еволюцію страхових відносин, які з моменту їх виникнення мали істотне значення для існування та діяльності людей, визначаючи рівень захищеності окремого індивіда від негативних явищ, протягом його життєвого шляху. Досліджуючи еволюцію страхових відносин, зверталася увага на стан розвитку суспільства загалом, відносини між основними верствами (станами) суспільства, рівень розвитку торговельних і договірних відносин. Так, зародження страхових відносин уже спостерігалося у перших східних державах у вигляді розкладки збитків між усіма учасниками торгового каравану у разі непередбаченої події (аварії, загибелі скота та ін.). 3 розвитком суспільства організація страхових відносин почала замінюватися та акумулюватися на основі постійного фонду - діяльність організацій статутного типу з обов'язковими страховими внесками. Їх можна вважати яскраво вираженими організаціями взаємного страхування на випадок смерті. Відносини взаємодопомоги регулювалися статутами і угодами колегій, додатковим захистом для виплати похоронних сум вважалась неможливість кредиторами стягнути їх. Подібна практика використовувалась і на території України і була зумовлена розвитком шляхової торгівлі, а прикладом страхової солідарності були українські чумаки. Розвиток торгівлі, ремесла, вдосконалення соціально-професійних відносин (діяльність цехів, гільдій) і суспільно-політичних явищ (збільшення кількості міст і міського населення) вплинули на необхідність підвищеного захисту населення від різних небезпек і спричинили удосконалення страхових відносин: реалізація морського страхування через спеціально створені страхові товариства, продаж страхових полісів, відшкодування збитків за умовами договору та інші. Починаючи з XIX ст. страхові відносини реалізувалися через об’єднання страховиків у концерни і призвели до більш чіткого розмежування видів страхування. Ставши невід'ємною частиною ринкової економіки (у XX ст.), страхові відносини стали одним із видів діяльності, пов'язаним з перерозподілом ризику завдання шкоди майновим інтересам серед учасників страхування (страхувальник, страховик). Отже, страхові відносини не залишалися незмінними, вони постійно збагачувалися залежно від форм господарювання, рівня їх розвитку, соціальної структури суспільства, функціонування публічної влади та інших факторів і поступово стали невід’ємним елементом функціонування суспільства.

Ключові слова: еволюція, страхові відносини, страхування, страхова справа, взаємодопомога.

\section{Summary}

Mykytiuk V. O. The insurance relations as a necessary element of the functioning of society. - Article.

In the article, the author is considering the evolution of insurance relations as a necessary element of the functioning of society, which since the moment of their emergence has had significant importance for the existence and activities of people, determining the level of a protection of an individual from all negative facts during their lifetime. Exploring the evolution of insurance relations, attention was paid to the level of development of society in general, the relations between the main layers of society, the level of development of trade and contractual relations. Thus, the inception of insurance interests had already been observed in the first eastern states in the form of distribution of losses between all members of trading caravan in case of emergency (accident, death of livestock, etc.). With the development of society, the organization of insurance relations began to be replaced and accumulated on the basis of a permanent fund - the activities of statutory organizations with compulsory insurance premiums. They can be considered as pronounced mutual insurance organizations in case of death. Relations of mutual assistance were regulated by statues and agreements of the boards, and the inability of creditors to collect them was considered as an additional protection for the payment of funeral sums. A similar practice was used on the territory of Ukraine and was due to the development of track trade, and an example of insurance solidarity were the Ukrainian Chumaks. The development of trade, craft, improvement of social and professional relations (the activity of workshops and guilds) and socio-political phenomena (increasing the number of towns and urban population) influenced the need for increased protection of the population from dangers and led to improved insurance relations: the implementation of marine insurance through specially created insurance companies, sale of insurance policies, indemnification under the terms of the contract and others. Since the XIX century insurance relations were realized through the amalgamation of insurers into concerns and led to a clearer delineation of types of insurance. Having become an important part of market economy (in the XX century), insurance relations became one of the kinds of activity associated with redistribution of the risk of harm to property interests among insurance participants (insured, insurer). Thus, insurance relations did not remain unchanged, they were constantly enriched depending on the forms of management, their level of development, social structure of society, the functioning of public authority and other factors and gradually became an integral part of the functioning of society.

Key words: evolution, insurance relations, insurance, insurance business, mutual assistance. 